\title{
PENGARUH KUALITAS PELAYANAN TERHADAP KEPUASAN MAHASISWA
}

\section{Sri Bulkia}

Universitas Islam Kalimantan Muhammad Arsyad Al-Banjary Banjarmasin

E-mail: kiasyah30@gmail.com

\begin{abstract}
The objective of this study is to determine how much influence the service quality to the students' satisfaction. Quality of care consists of five indicators. They are reliability, responsiveness, comfort (Assurance), awareness (Empathy), and the form of appearance (Tangibles). The population of thisstudy is all active students of the second semester 2014/2015 at the Islamic University of Kalimantan (UNISKA) Muhammad Arsyad Al Banjary Banjarmasin. Total population of this study is 8929. The sampling method using Slovin formula. It is chosen 99 samples. The results of study found that all of these hypotheses have been proven significantly. Service quality significantly influenced the students' satisfaction, the correlation coefficient is 0.697 and determination coefficient is 0.486 for the academic part, a correlation coefficient is 0.650 and determination coefficient is 0.423.For subdivision of the Student, the correlation coefficient is 0.630 and determination coefficient is 0.397. For the finance department, the correlation coefficient is 0.744 and determination coefficient is 0.553 . For the library subdivision, a correlation coefficient is 0.691 and determination coefficient is0.477, for new admissions students, the correlation coefficient is 0.731and determination coefficient is 0.534. For part of the faculty, the implication of service quality in this research has an important role, either individually or simultaneously in improving the students' satisfaction.
\end{abstract}

Keywords: Service Quality, Students' Satisfaction

\begin{abstract}
Abstrak
Tujuan penelitian ini adalah untuk mengetahui seberapa besar pengaruh kualitas pelayanan terhadap kepuasan mahasiswa. Kualitas pelayanan terdiri dari lima indikator yaitu kehandalan (Realibility), ketanggapan (Responsiveness), kenyamanan (Assurance), kepedulian (Emphaty), dan wujud penampilan (Tangibles). Populasi pada penelitian ini adalah seluruh mahasiswa aktif semester genap 2014 / 2015 pada Universitas Islam Kalimantan (Uniska) Muhammad Arsyad Al Banjary Banjarmasin yang berjumlah 8.929 orang. Metode pengambilan sampel menggunakan rumus Slovin didapat jumlah sampel 99 orang responden. Hasil penelitian menemukan bahwa seluruh hipotesis dalam penelitian ini telah terbukti secara signifikan. Kualitas Pelayanan berpengaruh secara signifikan terhadap kepuasan mahasiswa, koefisien korelasi sebesar 0,697 dan koefisien determinasi sebesar 0,486 untuk bagian akademik, koefisien korelasi sebesar 0,650 dan koefisien determinasi sebesar 0,423 untuk bagian kemahasiswaan, koefisien korelasi sebesar 0,630 dan koefisien determinasi sebesar 0,397 untuk bagian keuangan,koefisien korelasi sebesar 0,744 dan koefisien determinasi sebesar 0,553 untuk bagian perpustakaan, koefisien korelasi sebesar 0,691 dan koefisien determinasi sebesar 0,477 untuk penerimaan mahasiswa baru, serta koefisien korelasi sebesar 0,731 dan koefisien determinasi sebesar 0,534 untuk bagian fakultas. Implikasi pada penelitian ini adalah kualitas pelayanan memiliki peran yang sama penting baik secara individual ataupun secara simultan dalam meningkatkan kepuasan mahasiswa.
\end{abstract}

Kata kunci: Kualitas Pelayanan, Kepuasan Mahasiswa 


\section{PENDAHULUAN}

Perguruan tinggi swasta merupakan salah satu alternatif untuk menghadapi fenomena meningkatnya permintaan masyarakat terhadap kebutuhan pendidikan tinggi saat ini. Keadaan persaingan yang cukup kompetitif antar perguruan tinggi menuntut lembaga pendidikan memperhatikan mutu pendidikan dan kelembagaan sehingga mampu serta unggul dalam persaingan tersebut.

Dengan semakin bertambahnya jumlah perguruan tinggi menyebabkan persaingan semakin ketat, terutama dalam memberikan pelayanan kepada mahasiswa. Sebagai salah satu dari sekian banyak Universitas yang sudah dikenal oleh masyarakat luas, Universitas Islam Kalimantan Muhammad Arsyad Al Banjary Banjarmasin menyadari akan pentingnya hal tersebut.

Universitas Islam Kalimantan Muhammad Arsyad Al Banjary Banjarmasin mempunyai enam bagian pelayanan yaitu bagian pelayanan akademik, kemahasiswaan, keuangan, perpustakaan, penerimaan mahasiswa baru dan fakultas. Kesemua bagian pelayanan tersebut diharapkan dapat memberikan pelayanan yang berkualitas sehingga tercipta kepuasan mahasiswa.

Kunci mencapai tujuan perusahaan adalah dengan memenuhi dan memuaskan kebutuhan dan keinginan pelanggan.Kualitas pelayanan adalah hasil persepsi yang ditimbulkan setelah menerima pelayanan.Perceived service quality terbentuk setelah pelanggan membandingkan antara kualitas pelayanan yang mereka terima dan yang mereka harapkan. Kualitas pelayanan digambarkan sebagai bentuk sikap, berhubungan namun tidak sama dengan kepuasan, yang diperoleh dengan membandingkan harapan dengan performance (Bolton dan Drew, 1991; Parasuraman, Zeithaml, dan Berry 1998).

Perusahaan harus dapat memberikan nilai tersendiri bagi konsumen melalui kualitas layanan sehingga konsumen merasa puas dan tidak akan beralih kepada pesaing. Kepuasan pelanggan merupakan salah satu tujuan utama perusahaan dalam melakukan bisnisnya (Ardianto, 1996 ; Mc Dougall dan Levesque, 2000).

Konsep Islam mengajarkan bahwa dalam memberikan layanan dari usaha yang dijalankan baik itu berupa barang atau jasa jangan memberikan yang buruk atau tidak berkualitas, melainkan yang berkualitas kepada orang lain. Hal ini tampak dalam AlQuran surat Al-Baqarah ayat 267, yang menyatakan bahwa: "Hai orang-orang yang beriman, nafkahkanlah (dijalan Allah) sebagian dari hasil usahamu yang baik-baik dan sebagian dari apa yang kami keluarkan dari bumi untuk kamu dan janganlah kamu memilih yang buruk-buruk lalu kamu nafkahkan darinya padahal kamu sendiri tidak mau mengambilnya melainkan dengan memicingkan mata terhadapnya. Dan ketahuilah bahwa Allah Maha Kaya lagi Maha Terpuji”.

Dimensi reliable (kehandalan) yang berkenaan dengan kemampuan untuk memberikan jasa yang dijanjikan secara terpercaya dan akurat. Pelayanan akan dapat dikatakan reliabel apabila dalam perjanjian yang telah diungkapkan dicapai secara akurat.

Dimensi responsiveness (daya tanggap) berkenaan dengan kesediaan atau kemauan pegawai dalam memberikan pelayanan yang cepat dan tepat kepada konsumen.Kecepatan 
dan ketepatan pelayanan berkenaan dengan profesionalitas.

Dimensi assurance (jaminan) berkenaan dengan pengetahuan atau wawasan, kesopanan, santun, kepercayaan diri dari pemberi layanan, serta respek terhadap konsumen.

Dimensi empathy (empati) berkenaan dengan kemauan pegawai untuk peduli dan memberi perhatian secara individu kepada konsumen.Kemauan ini yang ditunjukkan melalui hubungan, komunikasi, memahami dan perhatian terhadap kebutuhan serta keluhan konsumen

Dimensi tangibles (bukti fisik) dapat berupa fasilitas fisik seperti gedung, ruangan yang nyaman, dan sarana prasarana lainnya.Dalam konsep Islam pelayanan yang berkenaan dengan tampilan fisik hendaknya tidak menunjukkan kemewahan

\section{TINJAUAN PUSTAKA}

\section{KUALITAS PELAYANAN}

Kualitas pelayanan mengacu pada penilaian konsumen terhadap inti dari pelayanan, penyedia dan organisasi pelayanan secara keseluruhan. Kualitas layanan dapat diartikan sebagai upaya pemenuhan kebutuhan dan keinginan konsumen serta ketepatan penyampaiannya dalam mengimbangi harapan konsumen" (Tjiptono, 2007:118).

Menurut Zeithaml (2009:7), faktor-faktor yang mempengaruhi kualitas layanan atau yang disebut dengan metode SERVQUAL adalah :

1.Reliability ( keandalan / dapat dipercaya )

\section{Responsiveness ( ketanggapan ).}

\section{Assurance ( Jaminan / kenyamanan )}

4.Empathy ( empati / perhatian khusus ).

5.Tangibles ( nyata / berwujud ).

Menurut (Johnson, 1998) ada lima dimensi Kualitas Layanan,yaitu :
1.Tangibles, yaitu penampilan fisik pelayanan ( fasilitas fisik, peralatan ), karyawan, dan komunikasi akan memberi warna dalam pelayanan pelanggan.

2.Reliability, yaitu kemampuan dalam memenuhi janji ( tepat waktu, konsisten, dan kecepatan pelayanan ) merupakan suatu hal yang terpenting dalam pelayanan.

3.Responsiveness, yaitu kepedulian untuk membantu pelanggan dan memberikan pelayanan yang baik adalah bagian dari pelayanan.

4.Assurance, yaitu pengetahuan dan sikap (tanggap, keramahan, kesopanan, bersahabat) dari pegawai dan kemampuan mereka dalam menanam kepercayaan dan kerahasiaan adalah diperlukan dalam pelayanan.

5.Emphaty, yaitu tingkat kepedulian dan perhatian perusahaan pada pelanggannya secara individu adalah sangat didambakan oleh pelanggan.

\section{KEPUASAN PELANGGAN}

Definisi kepuasan pelanggan menurut Howard \& Sheth ( dalam Tjipto dan Gregorius, 2011 : 297 )adalah situasi kognitif pembeli yang merasa dihargai setara atau tidak setara dengan pengorbanan yang dilakukannya. Apabila harapan pelanggan tidak sesuai dengan yang diharapkan, maka akan timbul ketidakpuasan yang berakibat pada sifat negatif terhadap merek maupun produsen, adanya keluhan atau komplain.

Berdasarkan uraian di atas maka dihipotesiskan :

\section{H1 : Kualitas Pelayanan berpengaruh terhadap Kepuasan Mahasiswa.}

\section{KERANGKA PENELITIAN}

Dalam penelitian ini yang menjadi variabel bebas (independent variable) ialah variabel kualitas pelayanan sedangkan variabel terikat (dependent variable) yaitu variabel kepuasan mahasiswa. Adapun model 
yang diusulkan dapat dilihat pada gambar 1 dibawah ini:

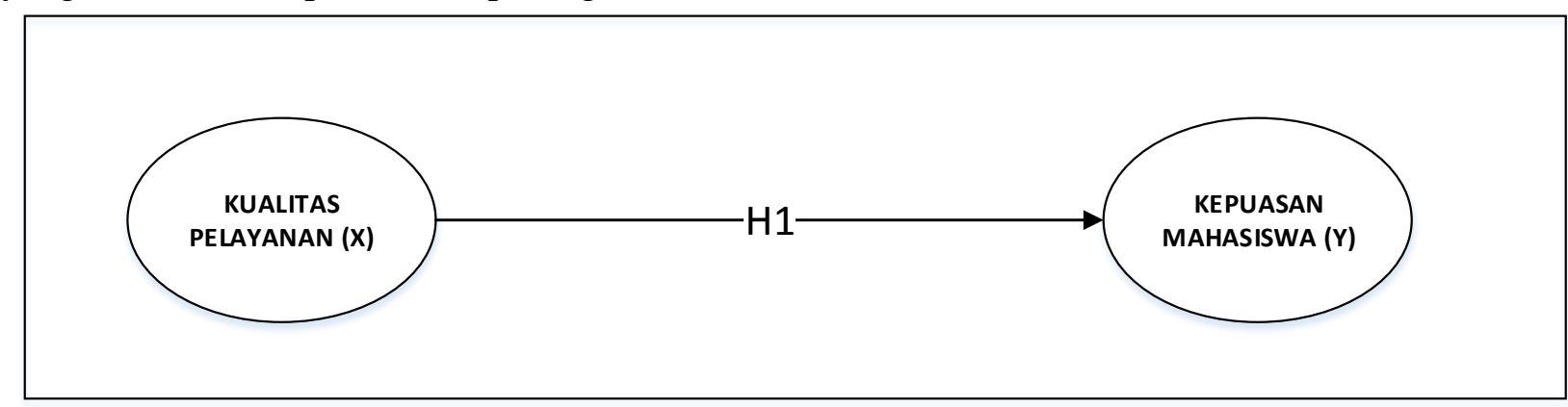

Gambar 1 Pengaruh Kulitas Pelayanan (X) terhadap Kepuasan Mahasiswa (Y)

Keterangan:

$\mathrm{H}_{1}$ : Kualitas Pelayanan berpengaruh positif dan signifikan terhadap Kepuasan Mahasiswa

$\mathrm{H}_{0}$ : Kualitas Pelayanan berpengaruh tidak signifikan terhadap Kepuasan Mahasiswa

\section{METODE PENELITIAN}

\section{POPULASI DAN SAMPEL PENELITIAN}

Jenis penelitian yang digunakan adalah penelitian eksplanatory yang bersifat asosiatif, merupakan penelitian yang bertujuan untuk mengetahui hubungan antara dua variabel atau lebih. Penelitian ini dilakukan di enam bagian pelayanan yaitu akademik, kemahasiswaan, keuangan, perpustakaan, penerimaan mahasiswa baru dan fakultas yang ada di Universitas Islam Kalimantan Muhammad Arsyad Al Banjary Banjarmasin.

Populasi yang digunakan dalam penelitian ini adalah seluruh mahasiswa aktif semester genap 2014/2015 pada Universitas Islam Kalimantan Muhammad Arsyad Al Banjary Banjarmasin yang berjumlah 8.929 orang mahasiswa. Jumlah mahasiswa aktif di Universitas Islam Kalimantan Muhammad Arsyad Al Banjary Banjarmasin dapat dilihat pada tabel 1 .

Sampel dalam penelitian ini adalah mahasiswa aktif semester genap 2014/2015 UNISKA yang mendapatkan pelayanan disemua bagian pelayanan. Jumlah sampel (n) yang akan diambil akan dihitung berdasarkan Teori Penetapan Jumlah Sampel Menurut Slovin, dimana peneliti menetapkan kesalahan ( e ) $10 \%$, sebagai berikut :

$$
n=\frac{N}{1+N(e)^{2}}
$$

$\mathrm{N}=$ ukuran sampel

$\mathrm{N}=$ ukuran populasi

$\mathrm{e}=$ persen kelonggaran ketidaktelitian karena kesalahan pengambilan sampel yang masih dapat ditolerer.

Dalam penelitian ini, $\mathrm{N}=8.929$ dan $\mathrm{e}=$ $10 \%$, maka :

$$
\begin{gathered}
n=\frac{8.929}{1+8929(0.1)^{2}} \\
n=\frac{8.929}{90,29} \\
n=98,89=99
\end{gathered}
$$

Berdasarkan hasil perhitungan rumus di atas, maka jumlah sampel minimal sebesar 99 dari 8.929 jumlah mahasiswa aktif Universitas Islam Kalimantan Muhammad Arsyad Al Banjary Banjarmasin yang tersebar pada berbagai prodi / jurusan.

\section{METODE PENGUMPULAN DATA}

Metode pengumpulan data merupakan salah satu aspek yang berperan dalam kelancaran dan keberhasilan dalam suatu penelitian. Dalam penelitian ini metode 
pengumpulan data yang digunakan adalah sebagai berikut:

\section{a. Studi pustaka}

Dimaksudkan untuk mendapatkan kajian dasar teoritis yang relevan dengan masalah yang diteliti.

\section{b. Kuesioner (angket)}

Dengan cara mengumpulkan data yang dilakukan dengan memberi seperangkat pertanyaan atau pernyataan tertulis kepada responden, dalam hal ini kuesioner disebarkan kepada 99 responden (mahasiswa). Pemberian skor/nilai terhadap jawaban pertanyaan pada kuesioner menggunakan skala Likert (Sugiyono,2001, hal 33). Pemberian skor dan kategori

jawaban pada tiap-tiap pertanyaan dalam kuesioner sebagai berikut :

$\begin{array}{ll}\text { Sangat Tidak Setuju } & =\text { skor } 1 \\ \text { Tidak Setuju } & =\text { skor } 2 \\ \text { Kurang Setuju } & =\text { skor } 3 \\ \text { Setuju } & =\text { skor } 4 \\ \text { Sangat Setuju } & =\text { skor } 5\end{array}$

\section{DEFINISI OPERASIONAL} VARIABEL

Definisi operasional variabel merupakan suatu definisi dan dinyatakan dalam kriteria yang dapat diuji secara khusus. Operasional variabel yang dikemukakan dalam penelitian ini meliputi :Variabel Bebas (Independent Variabel), yaitu variabel Kualitas Pelayanan (X) danVariabel Terikat (Dependent Variabel), yaitu variabel Kepuasan Mahasiswa.

Tabel 1

Jumlah populasi mahasiswa aktif Uniska

\begin{tabular}{|l|l|c|c|c|c|}
\hline \multirow{2}{*}{ No. } & \multirow{2}{*}{ Prodi / Jurusan } & \multicolumn{2}{|c|}{ Mahasiswa } & \multirow{2}{*}{ Jumlah } & Persentas \\
\cline { 3 - 4 } & & $\mathbf{L}$ & $\mathbf{P}$ & & $\mathbf{9})$ \\
\hline 1. & Agribisnis & 118 & 53 & 171 & 1,9 \\
\hline 2. & Administrasi Negara & 215 & 143 & 358 & 4,0 \\
\hline 3. & Bahasa Inggeris & 271 & 456 & 727 & 8,1 \\
\hline 4. & Bimbingan Konseling & 286 & 374 & 660 & 7,4 \\
\hline 5. & Ekonomi Syariah & 67 & 80 & 147 & 1,6 \\
\hline 6. & Hukum Ekonomi Syariah & 51 & 19 & 70 & 0,8 \\
\hline 7. & Ilmu Hukum & 458 & 148 & 606 & 6,8 \\
\hline 8. & Kesehatan Masyarakat & 401 & 514 & 915 & 10,2 \\
\hline 9. & Komunikasi & 137 & 73 & 210 & 2,4 \\
\hline 10. & Manajemen & 995 & 796 & 1791 & 20,1 \\
\hline 11. & Pendidikan Kimia & 27 & 67 & 94 & 1,1 \\
\hline 12. & Peternakan & 115 & 29 & 144 & 1,7 \\
\hline 13. & Teknologi Informasi & 1763 & 584 & 2347 & 26,3 \\
\hline 14. & Teknik Mesin & 517 & 4 & 521 & 5,8 \\
\hline 15. & Pascasarjana Komunikasi & 52 & 23 & 75 & 0,8 \\
\hline 16. & Pascasarjana Manajemen & 60 & 33 & 93 & 1,0 \\
\hline & $\quad$ JUMLAH & 5533 & 3396 & 8929 & 100 \\
\hline
\end{tabular}

Sumber : Bagian Akademik (BAAK) UNISKA. 
Tabel 2

Definisi Operasional Variabel

\begin{tabular}{|l|l|l|l|}
\hline \multicolumn{1}{|c|}{ Variabel } & \multicolumn{1}{|c|}{ Indikator } & \multicolumn{1}{c|}{ Item } & \multicolumn{1}{c|}{ Sumber } \\
\hline $\begin{array}{l}\text { Kualitas } \\
\text { Pelayanan }\end{array}$ & $\begin{array}{l}\text {-Keandalan } \\
\text {-Ketanggapan } \\
\text {-Kenyamanan } \\
\text {-Kepedulian } \\
\text {-Wujud penampilan }\end{array}$ & $\begin{array}{l}\text { Item 1,2 } \\
\text { Item 3 } \\
\text { Item 4,5,6 } \\
\text { Item 7,8 } \\
\text { Item 9,10 }\end{array}$ & Zeithaml (2009:7) \\
$\begin{array}{l}\text { Kepuasan } \\
\text { Mahasiswa }\end{array}$ & -Harapan & Item 1 & Fornell (1996) \\
\hline
\end{tabular}

\section{METODE ANALISIS DATA}

Analisis regresi linear berganda adalah analisis yang menghubungkan lebih dari dua variabel untuk mengetahui besarnya pengaruh dari suatu variabel terhadap variabel lainnya.

Variabel yang dipengaruhi disebut variabel tergantung atau variabel dependen, sedangkan variabel yang mempengaruhi disebut variabel bebas atau variabel independen (Nugroho, 2005).

Analisis regresi linear berganda (Sugiyono, 2007).Model regresi untuk kualitas pelayanan terhadap kepuasan mahasiswa adalah :

$\hat{Y}=\mathrm{a}+\beta_{1} \mathrm{X}_{1}+\beta_{2} \mathrm{X}_{2}+\beta_{3} \mathrm{X}_{3}+\beta_{4} \mathrm{X}_{4}+\beta_{5} \mathrm{X}_{5}+\mathrm{e}$

dimana:

$\mathrm{Y} \quad$ : Kepuasan Mahasiswa

$\mathrm{X} 1.1$ : Keandalan (Realibility)

$\mathrm{X} 1.2$ : Ketanggapan (Responsiveness)

X1.3: Kenyamanan (Assurance)

X1.4: Kepedulian (Emphaty)

X1.5: Wujud Penampilan (Tangibles)

A : konstanta, nilai $\hat{Y}$ jika $X=0$

$\beta \quad$ : angka arah atau koefisien regresi

e : kesalahan baku estimasi regresi

Dalam analisis ini teknik mencari regresi berganda dengan menggunakan output program SPSS (statistical package for social sciences) pada tabel coefficients.

\section{HASIL DAN PEMBAHASAN}

\section{DESKRIPSI HASIL PENELITIAN}

Dalam penelitian ini menggunakan model regresi berganda (Multiple Regression) untuk melihat pengaruh variabel bebas (independent variable) yaitu variabel kualitas pelayanan dengan variabel terikat (dependent variable) yaitu variabel kepuasan mahasiswa.

\section{a.Demografi Responden}

Hasil dari demografi responden menunjukkan bahwa berdasarkan jenis kelamin komposisi antara mahasiswa lakilaki dan perempuan tidak memiliki perbedaan yang besar, berdasarkan usia mahasiswa Universitas Islam Kalimantan Muhammad Arsyad Al Banjary di dominasi oleh usia muda dan Universitas Islam Kalimantan Muhammad Arsyad Al Banjary didominasi oleh jurusan Teknologi Informasi dan jurusan Manajemen.

\section{b. Statistik Deskriptif}

Statistika deskriptif dalam penelitian ini digunakan untuk menjelaskan analisis statistik sederhana untuk mengetahui sebaran 
dari jawaban yang diberikan responden yang di sajikan pada tabel 3 di bawah:

Tabel 3

Statistik Deskriptif

\begin{tabular}{|c|c|c|c|}
\hline Bagian Akademik & Mean & Std. Deviation & $\mathbf{N}$ \\
\hline Kepuasan Mahasiswa & 3,54 & ,940 & 99 \\
\hline Kualitas Pelayanan & 35,91 & 7,704 & 99 \\
\hline Bagian Kemahasiswaan & Mean & Std. Deviation & $\mathbf{N}$ \\
\hline Kepuasan Mahasiswa & 3,49 & ,919 & 99 \\
\hline Kualitas Pelayanan & 35,80 & 7,735 & 99 \\
\hline Bagian Keuangan & Mean & Std. Deviation & $\mathbf{N}$ \\
\hline Kepuasan Mahasiswa & 3,63 & ,910 & 99 \\
\hline Kualitas Pelayanan & 36,42 & 7,542 & 99 \\
\hline Bagian Perpustakaan & Mean & Std. Deviation & $\mathbf{N}$ \\
\hline Kepuasan Mahasiswa & 3,60 & ,925 & 99 \\
\hline Kualitas Pelayanan & 36,36 & 7,678 & 99 \\
\hline Bagian PMB & Mean & Std. Deviation & $\mathbf{N}$ \\
\hline Kepuasan Mahasiswa & 3,58 & ,938 & 99 \\
\hline Kualitas Pelayanan & 36,40 & 7,766 & 99 \\
\hline Bagian Fakultas & Mean & Std. Deviation & $\mathbf{N}$ \\
\hline Kepuasan Mahasiswa & 3,58 & 1,021 & 99 \\
\hline Kualitas Pelayanan & 35,95 & 7,684 & 99 \\
\hline
\end{tabular}

Tabel 4

Model Summary

\begin{tabular}{|l|c|c|c|c|c|}
\hline \multicolumn{1}{|c|}{$\begin{array}{c}\text { Bagian } \\
\text { Pelayanan }\end{array}$} & Model & R & R Square & $\begin{array}{c}\text { Adjusted Error } \\
\text { R Square }\end{array}$ & $\begin{array}{c}\text { Std } \\
\text { of the } \\
\text { Estimate }\end{array}$ \\
\hline Akademik & 1 &, 697 &, 486 &, 481 &, 678 \\
\hline Kemahasiswaan & 1 &, 650 &, 423 &, 417 &, 702 \\
\hline Keuangan & 1 &, 630 &, 397 &, 391 &, 710 \\
\hline Perpustakaan & 1 &, 744 &, 553 &, 548 &, 622 \\
\hline PMB & 1 &, 691 &, 477 &, 472 &, 682 \\
\hline Fakultas & 1 &, 731 &, 534 &, 529 &, 701 \\
\hline
\end{tabular}

a. Predictors: (Constant), Kualitas Pelayanan

b. Dependent Variable: Kepuasan Mahasiswa 


\section{PEMBAHASAN}

Hasil uji signifikansi menunjukkan bahwa hubungan antara variabel dependen dengan variabel independennya untuk bagian pelayanan akademik adalah sebesar 48,1 persen, bagian pelayanan kemahasiswaan sebesar 41,7 persen, bagian pelayanan keuangan sebesar 39,1 persen, bagian pelayanan perpustakaan sebesar 54,8 persen, bagian pelayanan penerimaan mahasiswa baru sebesar 47,2 persen, dan bagian pelayanan fakultas sebesar 52,9 persen.

Hasil perhitungan kualitas pelayanan terhadap kepuasan mahasiswa di semua bagian pelayanan menunjukkan nilai rata-rata di bawah 60 persen, sedangkan sisanya ratarata 40 persen dipengaruhi faktor lain di luar model penelitian.

\section{Hasil Pengujian Hipotesis}

Berdasarkan data yang diperoleh dari 99 responden, pembahasan hasil penelitian dilakukan untuk pengujian terhadap hipotesis yang telah dikemukakan dengan menggunakan program SPSS versi 18 secara ringkas diberikan sebagai berikut :

Hipotesis :

H0: kualitas pelayanan tidak berpengaruh secara signifikan terhadap kepuasan mahasiswa.

H1: kualitas pelayanan berpengaruh secara signifikan terhadap kepuasan mahasiswa.

Dari hasil perhitungan komputer program SPSS dengan memperhatikan besarnya koefisien korelasi (R) sebesar $+0,697$ untuk bagian akademik, korelasi (R) sebesar $+0,650$ untuk bagian kemahasiswaan,korelasi (R) sebesar $+0,630$ untuk bagian keuangan, korelasi (R) sebesar $+0,744$ untuk bagian perpustakaan, korelasi (R) sebesar $+0,691$ untuk bagian penerimaan mahasiswa baru, dan korelasi (R) sebesar
$+0,731$ untuk bagian fakultas, maka dapat dinyatakan bahwa hubungan antara Kualitas Pelayanan terhadap Kepuasan Mahasiswa adalah sangat kuat. Artinya semakin ditingkatkan Kualitas Pelayanan, maka akan mampu meningkatkan Kepuasan Mahasiswa.

Nilai t-tabel dengan alpha 5\% dan banyaknya sampel 99 responden diperoleh nilai 0,196.Berdasarkan hasil perhitungan didapat nilai t-hitung sebesar $+9,576$ untuk bagian akademik, nilai t-hitung sebesar $+8,428$ untuk bagian kemahasiswaan,nilai thitung sebesar $+7,987$ untuk bagian keuangan,nilai t-hitung sebesar $+10,955$ untuk bagian perpustakaan,nilai t-hitung sebesar $+9,408$ untuk bagian penerimaan mahasiswa baru,nilai t-hitung sebesar $+10,541$ untuk bagian fakultas, dan jika dibandingkan dengan t-tabel sebesar 0,196 dapat dinyatakan bahwa t-hitung > t-tabel serta probabilitas sig $=0,0000<0,05$ sehingga $\mathrm{H} 0$ ditolak dan $\mathrm{H} 1$ diterima. Jadi dapat dinyatakan bahwa kualitas pelayanan berpengaruh secara signifikan terhadap kepuasan mahasiswa.

Adapun besarnya pengaruh kualitas pelayanan tersebut di bagian akademik dapat diketahui dari koefisien determinasi (R2) sebesar 0,486 yang artinya bahwa sebesar $48,6 \%$ jumlah kualitas pelayanan secara signifikan mempengaruhi kepuasan mahasiswa dan sisanya sebesar $51,4 \%$ kepuasan mahasiswa dipengaruhi oleh faktor lain. Di bagian kemahasiswaan koefisien determinasi (R2) sebesar 0,423 yang artinya bahwa sebesar $42,3 \%$ jumlah kualitas pelayanan secara signifikan mempengaruhi kepuasan mahasiswa dan sisanya sebesar $57,7 \%$ kepuasan mahasiswa dipengaruhi oleh faktor lain. Di bagian keuangan koefisien determinasi (R2) sebesar 0,397 yang artinya bahwa sebesar $39,7 \%$ jumlah kualitas 
pelayanan secara signifikan mempengaruhi kepuasan mahasiswa dan sisanya sebesar $60,3 \%$ kepuasan mahasiswa dipengaruhi oleh faktor lain. Di bagian perpustakaan koefisien determinasi (R2) sebesar 0,553 yang artinya bahwa sebesar $55,3 \%$ jumlah kualitas pelayanan secara signifikan mempengaruhi kepuasan mahasiswa dan sisanya sebesar 44,7\% kepuasan mahasiswa dipengaruhi oleh faktor lain. Di bagian penerimaan mahasiswa barukoefisien determinasi (R2) sebesar 0,477 yang artinya bahwa sebesar $47,7 \%$ jumlah kualitas pelayanan secara signifikan mempengaruhi kepuasan mahasiswa dan sisanya sebesar $52,3 \%$ kepuasan mahasiswa dipengaruhi oleh faktor lain dan di bagian fakultas koefisien determinasi (R2) sebesar 0,534 yang artinya bahwa sebesar 53,4\% jumlah kualitas pelayanan secara signifikan mempengaruhi kepuasan mahasiswa dan sisanya sebesar $46,6 \%$ kepuasan mahasiswa dipengaruhi oleh faktor lain.

Tabel 5

Statistik Inferensial

\begin{tabular}{|c|c|c|c|c|c|c|}
\hline \multirow[t]{2}{*}{ Bagian Pelayanan } & \multirow[t]{2}{*}{ Model } & \multicolumn{2}{|c|}{ Unstandardized } & \multirow{2}{*}{\begin{tabular}{|c|} 
Standardized \\
Beta \\
\end{tabular}} & \multirow[b]{2}{*}{$\mathbf{t}$} & \multirow[b]{2}{*}{ Sig. } \\
\hline & & $\mathbf{B}$ & SE & & & \\
\hline \multirow[t]{2}{*}{ Akademik } & \multirow{2}{*}{\begin{tabular}{|l} 
(Constant) \\
Kualitas Pelayanan
\end{tabular}} &, 480 & ,326 & & 1,473 &, 144 \\
\hline & &, 085 &, 009 & ,697 & 9,576 &, 000 \\
\hline \multirow[t]{2}{*}{ Kemahasiswaan } & \multirow{2}{*}{\begin{tabular}{|l} 
(Constant) \\
Kualitas Pelayanan \\
\end{tabular}} & ,730 &, 336 & & 2,176 &, 032 \\
\hline & &, 077 &, 009 &, 650 & 8,428 &, 000 \\
\hline \multirow[t]{2}{*}{ Keuangan } & \multirow{2}{*}{$\begin{array}{l}\text { (Constant) } \\
\text { Kualitas Pelayanan }\end{array}$} &, 858 &, 354 & & 2,423 &, 017 \\
\hline & &, 076 &, 010 & ,630 & 7,987 &, 000 \\
\hline \multirow[t]{2}{*}{ Perpustakaan } & \multirow{2}{*}{$\begin{array}{l}\text { (Constant) } \\
\text { Kualitas Pelayanan } \\
\end{array}$} &, 338 &, 304 & & 1,113 & ,268 \\
\hline & & ,090 & ,008 & ,744 & 10,955 &, 000 \\
\hline \multirow[t]{2}{*}{ PMB } & \multirow{2}{*}{\begin{tabular}{|l} 
(Constant) \\
Kualitas Pelayanan \\
\end{tabular}} & ,539 & ,330 & & 1,634 &, 106 \\
\hline & & ,083 &, 009 & 691 & 9,408 &, 000 \\
\hline \multirow[t]{2}{*}{ Fakultas } & \multirow{2}{*}{$\begin{array}{l}\text { (Constant) } \\
\text { Kualitas Pelayanan }\end{array}$} & 085 &, 339 & &, 252 &, 802 \\
\hline & & ,097 & ,009 & ,731 & 10,541 & ,000 \\
\hline
\end{tabular}

a.Dependent Variable : Kepuasan Mahasiswa

\section{E. KESIMPULAN DAN SARAN}

Kualitas pelayanan berpengaruh secara signifikan dan dengan arah positif terhadap kepuasan mahasiswa di semua bagian pelayanan yang ada di Universitas Islam Kalimantan (Uniska) Muhammad Arsyad Al Banjary Banjarmasin. Berarti secara teoritis pengaruh kualitas pelayanan terhadap kepuasan mahasiswa ialah searah. Hal ini memberi makna, jika persepsi kualitas pelayanan terhadap kepuasan mahasiswa diterapkan pada semua bagian pelayanan yang ada di Universitas Islam Kalimantan (Uniska) Muhammad Arsyad Al Banjary Banjarmasin semakin baik dan positif, maka kepuasan mahasiswa akan semakin tinggi. Sebaliknya, jika persepsi kualitas pelayanan terhadap kepuasan mahasiswa diterapkan pada semua bagian pelayanan yang ada di Universitas Islam Kalimantan (Uniska) Muhammad Arsyad Al Banjary Banjarmasin kurang baik (negatif), maka kepuasan semakin rendah. Adapun besarnya pengaruh kualitas pelayanan terhadap kepuasan mahasiswa di semua bagian pelayanan 
menunjukkan nilai rata-rata di bawah 60 persen, sedangkan sisanya rata-rata 40 persen dipengaruhi faktor lain yaitu kualitas dosen, fasilitas belajar mengajar, biaya kuliah yang relatif murah (bisa diangsur) dan lain sebagainya.

Bagi Pimpinan Universitas Islam Kalimantan (Uniska) Muhammad Arsyad Al Banjary Banjarmasin, perlunya dukungan kualitas pelayanan berupa peningkatan keandalan, ketanggapan, kenyamanan, kepedulian dan wujud penampilan dengan cara memberikan pelatihan (trainning)dan seminar-seminar mengenai kualitas pelayanan untuk tenaga pelayanan yang ada di semua bagian pelayanan baik tenaga pelayanan yang baru maupun yang sudah lama sehingga mendorong untuk memberikan pelayanan yang terbaik terhadap mahasiswa demi tercapainya kepuasan bagi mahasiswa, untuk tenaga pelayanan di semua bagian pelayanan Universitas Islam Kalimantan Muhammad Arsyad Al Banjary Banjarmasin harus lebih giat lagi meningkatakan kualitas pelayanan demi tercapainya kepuasan mahasiswa akan pelayanan yang diharapkannya dengan cara berprinsip bahwa mahasiswa adalah raja yang harus diberikan pelayanan yang terbaik.

\section{DAFTAR PUSTAKA}

Amirin T., 2011, Populasi dan Sampel Penelitian 4 : Ukuran Sampel Rumus Slovin, Erlangga, Jakarta.

Ardianto, Eka, 1996,"Mengelola Nilai Konsumen,"Forum Manajemen Prasetya Mulya, No.64, pp.10-17.

Bolton, R.N, dan Drew, J.H., 1991, A Mustistage Model of Cosumers Assaesment of Servie Quality and Value, Journal of Consumer Research.
Fornell et al, "The American Customer Satisfaction Index, Nature Purpose, and Finding", Journal of Marketing vol 60, p 7-18 okt, 1996.

Gordon H.G. Mc Dougall and Terrence Levesque (2000),"Customer Statisfaction with Service : putting perceived value into the equetion" Journal of Service Marketing, vol.14, No.5.p.392-410.

Johnson Michael D, Customer Orientation and Market Action, Library of Congres Cataloging in Publishing Data 1998.

Kotler, Philip. Marketing Management: The Determinant of Perceived Service Quality and its Relationship with Satisfaction."Journal of Service Marketing”. 2000. pp. 217-229.

Nugroho, B.A, 2005. Strategi Jitu Memilih Metode Statistik Penelitian dengan SPSS. Yogyakarta : Andi Offset.

Oscar Yulius,2010. "Smarter \& Faster mengerjakanStatistika" SPSS 18.Yogyakarta :PanserPustaka.

Parasuraman. V.A Zeithaml, Leonard L Berry.1998.SERVQUAL:A multipleItem Scale for Measuring Consumer Perceptions of Service Quality. Journal of Retailing. Vol 64. No.1.

Slovin, Husein Umar, 2000, Riset Pemasaran dan Perilaku Konsumen Cetakan Ketiga, Jakarta : PT. Gramedia Pustaka Utama.

Sugiyono, 2001. Metode Penelitian Bisnis Alfabeta, Bandung.

Tjiptono, F. 2007. StrategiPemasaran. EdisiPertama. Yogyakarta :Andi Offset.

Tjiptono, Fandy ; Chandra Gregorius, 2011. Service Quality \& Statisfaction Edisi 3. Yogyakarta : Penerbit Andi.

Zeithaml, Valarie .A, Bitner, Mary Jo, and Gremler, Dwayne .D (2009), Service Marketing : Integrated Customer Focus Across the Firm, Mc Graw - Hill Education (uk) limited. 